\title{
IMPACT OF INTELLECTUAL CAPITAL ON INNOVATION CAPABILITY AND ORGANIZATIONAL PERFORMANCE: AN EMPIRICAL INVESTIGATION
}

\author{
Waseem Barkat ${ }^{a, b}$, Loo-See Beh ${ }^{a}$, Adeel Ahmed ${ }^{b}$ and Riaz Ahmed ${ }^{b}$

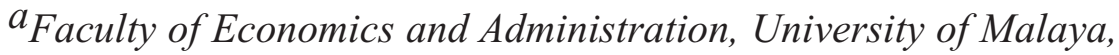 \\ 50603 Kuala Lumpur, Malaysia

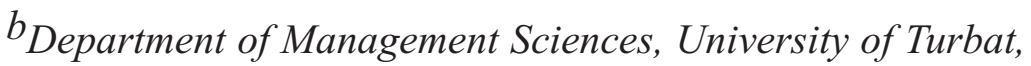 \\ Turbat-92600, Balochistan, Pakistan
}

(Received 31 March 2018; accepted 29 September 2018)

\begin{abstract}
Intellectual capital has much contribution for organizational value creation in developed nations, but it is still in progressing stages in developing countries. This study aims to develop a model to investigate the effects of different dimensions of intellectual capital on innovation capability and organizational performance. Data were collected from 295 respondents in large textile companies in Pakistan. This study found significant positive direct and indirect effects on innovation capability and organizational performance among three dimensions of intellectual capital: human, relational, and technological. This research presents the implications for HR managers and policy makers in incorporating intellectual capital. This study contributes to bridge the gap in research by examining the effects of different dimensions of intellectual capital on organizational performance in the context of a developing country.
\end{abstract}

Keywords: human capital, structural capital, relational capital, technological capital, innovation capability

\section{INTRODUCTION}

Intellectual Capital (IC) is considered one of the most crucial intangible assets in today's knowledge-based economy and is a pivotal element in the value creation of an organization (Chen et al., 2005). In this context, IC plays a vital role in achieving organizational success in a competitive environment (Lev, 2000; Subramaniam \&

\footnotetext{
* Corresponding author: wasimbarkat@gmail.com
}

DOI: $10.5937 /$ sjm13-16997 
Youndt, 2005). The major elements of a production-based economy are land, labor, capital, and physical assets. However, IC has changed the traditional organizational behavior in this era of competitive knowledge-based economy; it is regarded as an added value to physical assets (Bueno et al., 2004). Competition without innovation capability has a negative impact on firm growth (Sivalogathasan \& $\mathrm{Wu}, 2015)$. Raymond et al. (2013) asserted that innovation capability leads to organizational growth and productivity.

Extensive literature has investigated the various roles of IC and its conceptualizations with innovation which result in firm performance (Ar \& Baki, 2011; Leitner, 2015). The present research divides IC into four dimensional concepts namely, human capital, structural capital, relational capital, and technological capital (Bontis, 1999; Bueno et al., 2004; Roos et al., 1997; Stewart, 1997). Human capital is regarded as the knowledge, skills, satisfaction, and motivation of employees (Bontis et al., 2000). Structural capital refers to organizational structure, procedures, and processes, and administrative programs (Bontis et al., 2000; Roos et al., 1997). Relational capital denotes the relations with customers and suppliers and their loyalty toward an organization (Kim \& Kumar, 2009). Technological capital refers to information and technological knowledge, operations, and research and development (R\&D) (García-Muiña \& PelechanoBarahona, 2008; Khalique et al., 2015).

Trott (2008) described innovation as an engine of growth. The current study utilizes the concept of innovation capability, which comprises of product and process innovations (Ar \& Baki, 2011). Product innovation refers to the process of creation and subsequent introduction of a product, while process innovation means the implementation of new or significantly improved production (Atuahene-Gima, 1995; Massa \& Testa, 2008).

Despite the importance of IC and its vital role in organizational performance, few studies have been conducted to explore the effects of different dimensions of IC (human capital, structural capital, relational capital, and technological capital) on organizational performance (Bontis et al., 2000; Wang \& Chang, 2005). A research gap exists in terms of investigating the effects of different dimensions of IC on organizational performance in a developing country. In addition, IC and innovation capability have a fragmented relationship (Leitner, 2015). Innovation has a profound impact on the economy as well, but literature available on the subject to measure how a firm's IC contributes to innovation (Santos-Rodrigues et al., 2010) and in-depth studies of IC dimensions and innovation (Subramaniam \& Youndt, 2005) are lacking. Verbano and Crema (2016) also reiterated the importance of exploring IC components in terms of how they influence innovation and performance. Hence, this study will also investigate the mediating role of innovation capability between IC dimensions and organizational performance.

\section{LITERATURE REVIEW}

The framework of this study was developed based on resource-based theory. Resources have been found to be important antecedents to products and ultimately to companies performance (Wernerfelt, 1984; Grant, 1991). The resource-based theory addresses the issue that how to achieve 
competitive performance to the other organization. Similarly, the acquisition and exploitation of such distinctive resources leads to superior performance. Apart from traditional tangible resources, numerous scholars investigate the intangible resources such as IC (human, structural, relation, and technological capital) and their effect on organizational performance (Asiaei \& Jusoh, 2015; Bontis, 1998; Bontis et al., 2000). Therefore, resource based theory is used to depict the relationship between IC dimensions and organizational performance (Figure 1).

\subsection{Aspects of IC and organizational performance}

The most important pillar of business organizations are employees, not buildings, cash, or equipment (Fitz-Enz, 2000). Human capital is a fundamental asset in an organization. According to Marimuthu et al. (2009), this capital increases the profitability of a firm and is a valuable asset for an organization to pave the way for future creativity. Bontis et al., 2000; Wang et al., 2014 argued that the well-utilized knowledge, skills, and abilities of individuals provide positive and significant organizational performance. Based on above discussion the following hypothesis is developed.

H1. A positive relationship exists between human capital and organizational performance.

Structural capital is the non-human reserve of knowledge which supports improved organizational performance in a competitive environment (Bontis, 1998; Stewart, 1997). Moreover, it not only improves the way an organization gathers, produces, and communicates knowledge but also attains a better position to generate better-quality products and processes with minimum cost and deep insights leading to business success (Zangoueinezhad \& Moshabaki, 2009).

H2. A positive relationship exists between structural capital and organizational performance.

Customers and suppliers who are externally linked with organizations are also suitable drivers of performance. Through relational capital, organizations expand their learning network and get updated methods for performing tasks. By building relations with customers and suppliers, organizations

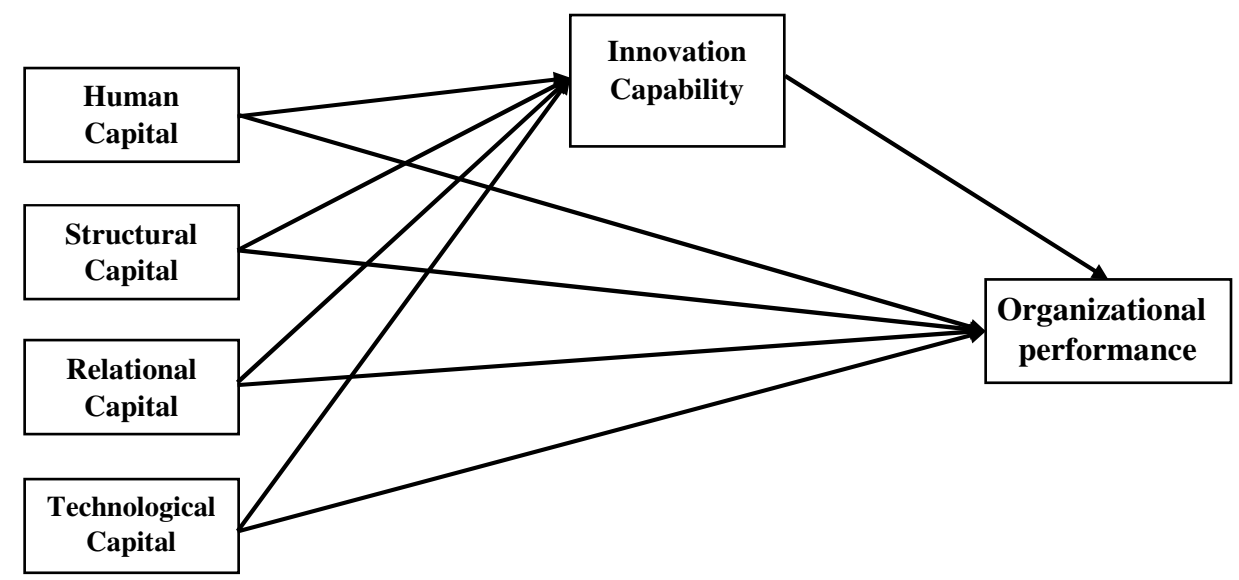

Figure 1. Theoretical framework 
become more innovative by learning from other experiences (Cousins et al., 2006; Dewhurst \& Cegarra Navarro, 2004). In addition, literature shows the negative effects of relational capital on performance (GarcíaMerino et al., 2014).

H3. A positive relationship exists between relational capital and organizational performance.

Among other dimensions of IC, technological capital offers a constructive role in organizational success. Khalique et al. (2015) noted that technological capital contributes to organizational performance. The role of ICT in a competitive and knowledge-based business environment cannot be denied. Such technology has become a basic requirement in order to adjust in a new business era by improving business practices and enhancing efficiency and competitiveness (McNamara, 2008). On the basis of the above discussion and relationships, the following hypotheses is developed.

H4. A positive relationship exists between technological capital and organizational performance.

\subsection{Mediating role of innovation capability}

Innovation capability performs the role of value addition for organizational success. Companies with product and process innovation and exporting capability can achieve substantial performance (Love \& Roper, 2015; Vila \& Kuster, 2007). Regardless of other factors, organizations with product and process innovation upgrade their performance faster than those without, and such product and process innovation improves organizational growth and productivity (Freel \& Robson, 2004; Roper et al., 2008).

Human capital with diverse knowledge, ideas, and skills consequently develop product innovation. Donate et al. (2016) revealed that the development of human capital is not an overnight process but rather takes years and is a core of innovation capability. The innovation capability of an organization can be largely affected if less attention is paid to human capital development. Thus, a hypothesis is drawn to be empirically tested.

H5. Innovation capability mediates the relationship between human capital and organizational performance.

Organizations can provide a good working space, a good database to reduce work hours, and platforms for interaction to discuss common organizational goals. Such structural facilities promote prevailing knowledge and influence innovation in the organization. Organizations with wellorganized structures, databases, and processes also support innovation (Subramaniam \& Youndt, 2005).

H6. Innovation capability mediates the relationship between structural capital and organizational performance.

The robust relations an organization has with external parties (customers and suppliers) are the most influential for achieving competitive advantage (Chahal \& Bakshi, 2015). Furthermore, involving customers who have a close relationship with a firm will lead to the enhanced progress of superior product and process innovation (Santos-Rodrigues et al., 2015).

H7. Innovation capability mediates the relationship between relational capital and organizational performance.

Organizations with modern ICT tools performs better in innovating new products and making changes to existing products to 
reduce cost. ICT support allows firms to monitor their competitors and quickly change their strategy according to the existing business situation. Similarly, ICT provides support to trace customers' demand and feedback, which are essential for developing new products according to customer taste (Mohsin et al., 2013). However, the role of ICT in developing and transition economies has not yet reached the satisfactory level, which may be attributed to the lack of basic ICT knowledge and skills in the organization. Hence, the below hypothesis is drawn to see its empirical impact.

H8. Innovation capability mediates the relationship between technological capital and organizational performance.

\section{METHODOLOGY}

This research relies on subjective measures for data analysis. Numerous studies have focused predominantly on subjective measures for IC and performance measurement (Asiaei \& Jusoh, 2015; Kannan \& Aulbur, 2004; Sharabati et al., 2010).

\subsection{Measurement}

This study adopted the previous survey instruments for data collection. The constructs were measured with a five-point Likert scale ranging from " $1=$ strongly disagree" to " $5=$ strongly agree." The items in human capital cover the knowledge level of employees', skills, motivation, and satisfaction and expertise, while structural capital was measured by organizational processes, procedures, administrative programs, infrastructure, and systems
(Bontis et al., 2000; Roos et al., 1997; Subramaniam \& Youndt, 2005). Relational capital encompasses a cooperative relationship with customers, suppliers, and government agencies, as well as loyalty and networking (Bontis et al., 2000; Khalique et al., 2015; Kim \& Kumar, 2009). Finally, technological capital was measured with ICT knowledge, R\&D, and technology operations (García-Muiña \& Pelechano-Barahona, 2008; Khalique et al., 2015).

The dependent variable organizational performance was measured with export growth, internal sales, profitability, management's perception of export profitability, and management's satisfaction to gauge export performance, new product development, value added per worker, output per worker, and cost of production (Schreyer, 2001; Singapore, 2011; Sousa, 2004; White et al., 1998). Lastly, the mediating variable innovation capability was measured with two main dimensions: product innovation (product quality, innovative features, new product development) and process innovation (production processes, modes of operations) (Atuahene-Gima, 1995; Henard \& Szymanski, 2001).

\subsection{Sampling and data collection}

The population of this study was based on the textile industry in Pakistan. This study focused large companies because, such companies can be more aware about the importance of IC and its application of innovation compared with SMEs. Moreover, companies with more than 400 employees were selected in the present study. Managerial-level employees were selected as a data collection sample. A total of 540 questionnaires were distributed. The method of data collection was surface mail and self- 
administrative method. A total of 306 questionnaires were returned, but only 295 questionnaires were usable, for a response rate of $54.62 \%$. The company and respondents profile is enlightened in Table 1.

\section{RESULTS AND DISCUSSION}

To assess the proposed relationship in the theoretical model, Partial Least Square (PLS) Structural Equation Modelling was employed. This approach is a popular methodology because of its flexible interplay between theory and data; it also bridges theoretical and empirical knowledge for a better understanding of the real world (Hair et al., 2011). The WarpPLS version 5.0 was used to perform PLS analysis (Kock, 2015).

\subsection{Assessment of the measurement model}

The measurement model examines the validity of the constructs tested through convergent validity, discriminant validity, and reliability according to the common criteria. The descriptive statistics consisting of the mean and standard deviation for each variable is shown in Table 2. Furthermore, Table 2 also depicts the discriminant validity that refers to the degree to which a latent variable differs from other latent variables. The recommended criterion for discriminant validity is that the square root of the AVE for each latent variable should be larger than any

Table 1. Company and Respondent profile

\begin{tabular}{|c|c|c|c|}
\hline \multicolumn{2}{|r|}{ Profiling } & \multirow{2}{*}{$\begin{array}{c}\text { Frequency } \\
183\end{array}$} & \multirow{2}{*}{$\frac{\text { Percentage }}{62}$} \\
\hline & Male & & \\
\hline Gender & Female & 112 & 38 \\
\hline \multirow{3}{*}{$\begin{array}{c}\text { Current job } \\
\text { position }\end{array}$} & First-line Manager & 138 & 47 \\
\hline & Mid-level Manager & 119 & 40 \\
\hline & Top-level Manager & 38 & 13 \\
\hline \multirow{4}{*}{$\begin{array}{l}\text { Years of job } \\
\text { experience }\end{array}$} & Less than 3 years & 45 & 15 \\
\hline & 3 to 5 years & 78 & 26 \\
\hline & 6 to 10 years & 105 & 36 \\
\hline & More than 10 years & 67 & 23 \\
\hline \multirow{3}{*}{$\begin{array}{l}\text { Number of } \\
\text { Employees }\end{array}$} & $401-699$ & 96 & 32 \\
\hline & $700-999$ & 114 & 39 \\
\hline & More than 1000 & 85 & 29 \\
\hline \multirow{5}{*}{$\begin{array}{l}\text { Years of } \\
\text { business } \\
\text { operation }\end{array}$} & $1-5$ years & 32 & 11 \\
\hline & $6-10$ years & 92 & 31 \\
\hline & 11- 15 years & 75 & 25 \\
\hline & 16 - 20 years & 46 & 16 \\
\hline & $>20$ years & 50 & 17 \\
\hline
\end{tabular}


correlations of that latent variable (Fornell \& Larcker, 1981). Table 2 shows that all the diagonal values in parentheses are greater than other squared correlations.

Table 3 shows the results of factor loading ranging from 0.534 to 0.891 . The loadings of all indicators fulfil the basic requirement, which is greater than 0.5 (Hair et al., 2009). The AVE ranges from 0.512 to 0.761 , exceeding the recommended cutoff value (Fornell \& Larcker, 1981). In this study, composite reliability ranges from 0.860 to 0.956 and Cronbach's alpha values are 0.804 to 0.949 , thus fulfilling the threshold value of 0.7 .

Block variance inflation factor (VIF) was used to check the multicollinearity issues among constructs. A block VIF with the value of 3.3 or lower suggests no multicollinearity among constructs (Kock \& Lynn, 2012). Table 4 shows a block of VIF ranging from 1.026 to 1.264 , which assures no multicollinearity among constructs.

\subsection{Assessment of the structural model}

The estimated model is shown in Figure 2. The fitness and quality of the model were evaluated with recommendations by $\mathrm{Ned}$ Kock (2015). The values of APC and ARS are $0.218(\mathrm{p}<0.001)$ and $0.394(\mathrm{p}<0.001)$, respectively. AVIF is also 1.12, which is in the range of acceptable value of 3.3. Finally, goodness of fit presents the model's explanatory power as 0.507 (small $\geq 0.1$, medium $\geq 0.25$, large $\geq 0.36$ ) .

Results of the hypothesis testing are reported in Tables 5 and 6 , respectively. $\mathrm{R}^{2}$ value, path coefficient, and effect size are also explained. The direct relation between human capital and organizational performance proved significant with a path coefficient value of $(\beta=0.183, \mathrm{P}=0.002)$, thus $\mathrm{H} 1$ is accepted. Similarly, relational capital $(\beta=0.410, \quad \mathrm{P}=0.000) \quad$ and technological capital $(\beta=0.229, \mathrm{P}=0.005)$ results supported $\mathrm{H} 3$ and $\mathrm{H} 4$, respectively. In comparison, H2 (structural capital and organizational performance) was not supported.

Table 6 shows the mediation analysis. An indirect effect of bootstrapping was applied by Preacher and Hayes (2008) to test the remaining hypotheses. The indirect effect of human capital to organizational performance $(\beta=0.136, P=0.000)$, relational capital to organizational performance $(\beta=0.125$, $\mathrm{P}=0.020)$ and, finally, technological capital to organizational performance $(\beta=0.06$, $\mathrm{P}=0.034)$ accepts $\mathrm{H} 5, \mathrm{H} 7$, and $\mathrm{H} 8$,

Table 2. Descriptive statistics and discriminant validity coefficients

\begin{tabular}{llllllllll}
\hline & Variables & Mean & SD & 1 & 2 & 3 & 4 & 5 & 6 \\
\hline 1 & Human capital & 4.148 & .892 & $\mathbf{( 0 . 8 4 2 )}$ & & & & & \\
2 & Structural capital & 4.139 & .436 & -0.065 & $\mathbf{( 0 . 8 7 2 )}$ & & & & \\
3 & Relational capital & 4.058 & .887 & 0.308 & -0.049 & $\mathbf{( 0 . 7 6 8 )}$ & & & \\
4 & $\begin{array}{l}\text { Technological } \\
\text { capital }\end{array}$ & 3.782 & 1.060 & 0.286 & 0.048 & 0.197 & $\mathbf{( 0 . 8 3 8 )}$ & & \\
5 & $\begin{array}{l}\text { Innovation } \\
\text { capability }\end{array}$ & 3.762 & .853 & 0.331 & -0.15 & 0.281 & 0.288 & $\mathbf{( 0 . 7 1 6 )}$ \\
6 & $\begin{array}{l}\text { Organizational } \\
\text { performance }\end{array}$ & 4.054 & .892 & 0.358 & -0.076 & 0.447 & 0.245 & 0.563 & $\mathbf{( 0 . 7 9 6 )}$ \\
$\quad$ Note: Diagonal in parentheses represents the square root of AVE. & & & & \\
\hline
\end{tabular}


Table 3. Factor Loadings and Reliability

\begin{tabular}{|c|c|c|c|c|}
\hline Constructs & Standardized loadings & AVE & $\mathbf{C R}$ & Cronbach's $\alpha$ \\
\hline Human capital & & 0.709 & 0.956 & 0.949 \\
\hline $\mathrm{HC} 1$ & .823 & & & \\
\hline $\mathrm{HC} 2$ & .843 & & & \\
\hline $\mathrm{HC} 3$ & .856 & & & \\
\hline $\mathrm{HC} 4$ & .823 & & & \\
\hline HC5 & .828 & & & \\
\hline HC6 & .848 & & & \\
\hline $\mathrm{HC} 7$ & .844 & & & \\
\hline $\mathrm{HC} 8$ & .845 & & & \\
\hline $\mathrm{HC} 9$ & .868 & & & \\
\hline Structural capital & & 0.761 & 0.950 & 0.937 \\
\hline $\mathrm{SC} 1$ & .859 & & & \\
\hline $\mathrm{SC} 2$ & .891 & & & \\
\hline $\mathrm{SC} 3$ & .854 & & & \\
\hline $\mathrm{SC} 4$ & .886 & & & \\
\hline SC5 & .874 & & & \\
\hline SC6 & .870 & & & \\
\hline Relational capital & & 0.590 & 0.878 & 0.826 \\
\hline $\mathrm{RC} 1$ & .803 & & & \\
\hline $\mathrm{RC} 2$ & .750 & & & \\
\hline RC3 & .782 & & & \\
\hline $\mathrm{RC} 4$ & .737 & & & \\
\hline RC5 & .765 & & & \\
\hline Technological capital & & 0.701 & 0.943 & 0.929 \\
\hline $\mathrm{TC} 1$ & .800 & & & \\
\hline TC2 & .765 & & & \\
\hline TC3 & .826 & & & \\
\hline TC4 & .890 & & & \\
\hline TC5 & .825 & & & \\
\hline TC6 & .871 & & & \\
\hline TC7 & .878 & & & \\
\hline Organizational performance & & 0.633 & 0.923 & 0.903 \\
\hline OP1 & .774 & & & \\
\hline $\mathrm{OP} 2$ & .831 & & & \\
\hline OP3 & .759 & & & \\
\hline OP4 & .830 & & & \\
\hline OP5 & .809 & & & \\
\hline OP6 & .802 & & & \\
\hline OP7 & .760 & & & \\
\hline Innovation capability & & 0.512 & 0.860 & 0.804 \\
\hline $\mathrm{InC} 1$ & .800 & & & \\
\hline $\mathrm{InC} 2$ & .810 & & & \\
\hline $\mathrm{InC} 3$ & .764 & & & \\
\hline $\mathrm{InC} 4$ & .775 & & & \\
\hline InC5 & .534 & & & \\
\hline InC6 & .555 & & & \\
\hline Note $. \mathrm{CR}=$ composite reliability & $=$ average variance extra & & & \\
\hline
\end{tabular}

Table 4. Block variance inflation factors

\begin{tabular}{lllll}
\hline Variables & HC & RC & TC & INC \\
\hline INC & 1.113 & 1.026 & 1.131 & \\
OP & 1.264 & 1.137 & 1.156 & 1.239 \\
Note: These VIFs are for the latent variables on each column (predictors), with & \\
reference to the latent variables on each row (criterion). & & \\
\hline
\end{tabular}




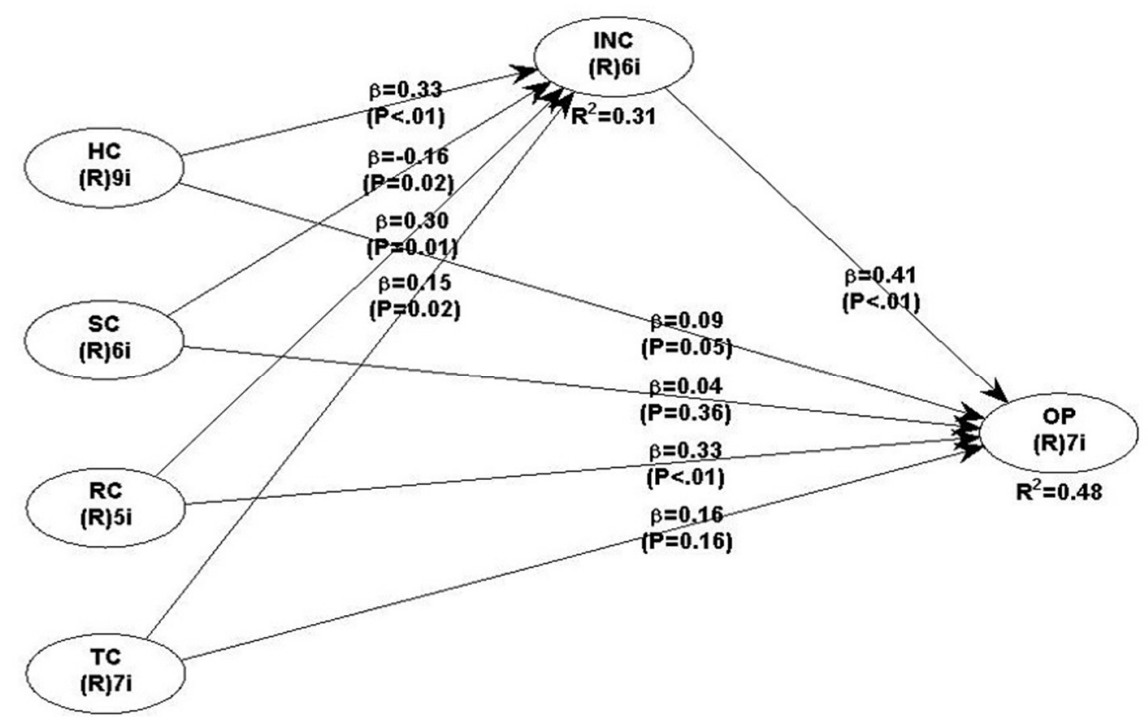

Figure 2. The estimated model

Table 5: Results of direct hypothesis testing (IC dimensions and OP)

\begin{tabular}{cccccc}
\hline Hypothesis & Paths & $\begin{array}{c}\text { Direct } \\
\text { Estimates }\end{array}$ & P value & Effect size & Decision \\
\hline H1 & HC-OP & 0.183 & 0.002 & 0.068 & Supported \\
H2 & SC-OP & -0.077 & 0.185 & 0.007 & Not Supported \\
& RC-OP & 0.410 & 0.000 & 0.200 & Supported \\
H3 & TC-OP & 0.229 & 0.005 & 0.076 & Supported \\
\hline
\end{tabular}

Table 6: Mediation analysis (indirect effect) of model

\begin{tabular}{ccccccc}
\hline \multirow{2}{*}{ Hypothesis } & Paths & $\begin{array}{c}\text { Direct } \\
\text { Estimates }\end{array}$ & $\begin{array}{c}\text { Indirect } \\
\text { Estimates } \\
\mathbf{a * b}\end{array}$ & P value & Effect size & Decision \\
\hline \multirow{2}{*}{ H5 } & HC-OP & 0.088 & & 0.05 & 0.032 & Supported \\
& HC-INC-OP & & 0.136 & 0.000 & 0.050 & \\
H6 & SC-OP & 0.036 & & 0.358 & 0.003 & Not Supported \\
& SC- INC -OP & & -0.065 & 0.024 & 0.006 & Supported \\
& RC-OP & 0.326 & & 0.000 & 0.160 & Supported \\
& RC-INC-OP & & 0.125 & 0.020 & 0.061 & 0.054 \\
\hline
\end{tabular}


respectively. The indirect effect of structural capital and organizational performance was insignificant, whereas H6 was not supported.

The findings of this study presented in Tables 5 and 6 found that the development of IC in terms of human capital has a significant effect on organizational performance. Developing human capital is undoubtedly important in a competitive business environment. The results are consistent with those in prior studies of Felício et al. (2014) and Wang et al. (2014), who also highlighted the role of human resource for a company's success. Outcomes also established that innovation capability has a partial mediating effect between human capital and organizational performance. Compared with other dimensions of IC, human capital has the strongest indirect effect on organizational performance and finding of this verifies that human capital works as a catalyst that enhances innovation in organizations.

Moreover, this research depicts that among IC dimensions, relational capital has the strongest significant direct effect on organizational performance. It shows that customers and suppliers are the crucial part of an organization. Companies can generate innovative ideas from their customer's choices, because the customers are the ultimate buyers of products and their knowledge is quite imperative for organizations. The findings are consistent with those of previous studies (Hormiga et al., 2011; Luo et al., 2004) and customers and suppliers are considered essential drivers to promote performance. This study tested and proved the significant indirect relationship between relational capital and organizational performance through innovative capability (Santos-Rodrigues et al., 2015; Wang et al., 2016). Customers and suppliers are one of the sources of a company's expertise. Sometime their ideas and feedback support the company, either what new things they need and what should be added or omitted in the existing products.

Additionally, the study result reveals the significant direct and indirect relationship between technological capital and organizational performance. Similar to other manufacturing industries, the textile industry is utilizing such technology to make itself competitive (McNamara, 2008). The effective utilization of ICT has a positive impact on product and process innovation (Mohsin et al., 2013). Thus, textile companies in Pakistan can employ such technology, which connects them with customers and suppliers both locally and internationally. Such technology can also increase company exports because it escalates the operational process and fulfils one-time orders from the clients.

Contrary to expectations, the insignificant direct and indirect effects of structural capital on organizational performance exist. One possible explanation for this may be the case of a developing country like Pakistan, where organizations are not well equipped with databases, operating processes, procedures, and better production planning. The result of this study are also aligned with Leitner (2015) who revealed that structural capital has a negative impact on profitability and growth. Management should apply effective organizational design by fulfilling all structural requirements, including processes, procedures, hierarchies, and systems.

\section{CONCLUSION}

In this study, a theoretical framework is tested by investigating the effects of 
individual dimensions of IC: (human, structural, relational, and technological) with innovation capability and the organizational performance of the textile industry in Pakistan. The empirical findings of this study portray that the textile industry acquires knowledge from different dimensions of IC to enhance organizational performance either directly or indirectly through innovation capability. All dimensions of IC depict significant positive direct and indirect effects on organizational performance, except for structural capital, which is insignificant both directly and indirectly.

The current study contributes to the body of knowledge in literature by adding technological capital as a part of IC, which has been considered important by researchers (Bueno et al., 2004). Previous literature discusses the role of technological capital as just a small part of a construct, but the current study broadly explains the concept as a separate construct. Study results confirm that technological capital has an immense contribution to organizational performance. Secondly, this study highlighted the individual dimensional role of IC with innovation capability and organizational performance. Such dimensional effect supports managers to invest in the most appropriate elements of IC to achieve organizational performance (Roos \& Roos, 1997).

Given that all IC dimensions may not be useful simultaneously but, managers should have appropriate knowledge to utilize the right dimension at the right time. Further, these dimensions of IC support managers and practitioners to apply such ideas for organization long-term benefits. In future researchers and practitioners can add more dimensions of IC and check its empirical effect on organizational performance.
Despite its contribution, this study has some limitations. First, this study focused only on the large textile industry in Pakistan. However, including other small and medium textile sectors and doing a comparative study could give a broader picture of the textile industry. Second, the nature of this study is cross sectional and all data are collected at a specific point in time. Third, the current study is limited to a single developing country, namely Pakistan; however, including other developing countries could give a broader picture of the textile industry.

\section{References}

Ar, M.I., \& Baki, B. (2011). Antecedents and performance impacts of product versus process innovation: Empirical evidence from SMEs located in Turkish science and technology parks. European Journal of Innovation Management, 14(2), 172-206.

Asiaei, K., \& Jusoh, R. (2015). A multidimensional view of intellectual capital: the impact on organizational performance. Management decision, 53(3), 668-697.

Atuahene-Gima, K. (1995). An exploratory analysis of the impact of market orientation on new product performance a contingency approach. Journal of product innovation management, 12(4), 275-293.

Bontis, N. (1998). Intellectual capital: an exploratory study that develops measures and models. Management decision, 36(2), 63-76.

Bontis, N. (1999). Managing organisational knowledge by diagnosing intellectual capital: framing and advancing the state of the field. International Journal of technology management, 18(5), 433-462.

Bontis, N., Keow , W.C.C., \& Richardson, 


\title{
УТИЦАЈ ИНТЕЛЕКТУАЛНОГ КАПИТАЛА НА ИНОВАЦИОНЕ СПОСОБНОСТИ И ОРГАНИЗАЦИОНЕ ПЕРФОРМАНСЕ: ЕМПИРИЈСКО ИСТРАЖИВАЫЕ
}

\author{
Waseem Barkat, Loo-See Beh, Adeel Ahmed, Riaz Ahmed
}

\begin{abstract}
Извод
Интелектуални капитал има велики допринос у стварању организационих вредности у развијеним земљама, али је још увек у почетним фазама у земљама у развоју. Ово студија има за циљ да развије модел истраживања ефеката различитих димензија интелектуалног капитала на способност иновирања и перформансе организације. Подаци су прикупљени од 295 испитаника у великим текстилним компанијама у Пакистану. Ова студија је утврдила значајне позитивне, директне и индиректне ефекте на иновациону способност и организационе перформансе међу три димензије интелектуалног капитала: људског, релационог и технолошког. Ово истрааживање даје извесне импликације за менаџере људских ресурса и креаторе политике у смислу укључивања интелектуалног капитала. Ова студија такође доприноси и умањењу јаза у испитивању ефеката утицаја различитих димензија интелектуалног капитала на организационе перформансе у контексу земаље у развоју.
\end{abstract}

Кључне речи: људски капитал, структурни капитал, релациони капитал, технолошки капитал, иновациона способност

S. (2000). Intellectual capital and business performance in Malaysian industries. Journal of Intellectual Capital, 1(1), 85-100.

Bueno, E., Paz Salmador, M., \& Rodríguez, Ó. (2004). The role of social capital in today's economy: Empirical evidence and proposal of a new model of intellectual capital. Journal of Intellectual Capital, 5(4), 556-574.

Chahal, H., \& Bakshi, P. (2015). Examining intellectual capital and competitive advantage relationship: role of innovation and organizational learning. International Journal of Bank Marketing, 33(3), 376-399.

Chen, Ming-Chin, Cheng, S.-J., \& Hwang, Y. (2005). An empirical investigation of the relationship between intellectual capital and firms' market value and financial performance. Journal of Intellectual Capital, 6(2), 159-176.
Cousins, P.D., Handfield, R.B., Lawson, B., \& Petersen, K.J. (2006). Creating supply chain relational capital: the impact of formal and informal socialization processes. Journal of Operations Management, 24(6), 851-863.

Dewhurst, F.W., \& Cegarra Navarro, J.G. (2004). External communities of practice and relational capital. The Learning Organization, 11(4/5), 322-331.

Donate, M.J., Peña, I., \& Sánchez de Pablo, J.D. (2016). HRM practices for human and social capital development: effects on innovation capabilities. The International Journal of Human Resource Management, 27(9), 928-953.

Felício, J.A., Couto, E., \& Caiado, J. (2014). Human capital, social capital and organizational performance. Management decision, 52(2), 350-364.

Fitz-Enz, J. (2000). ROI of human capital: Measuring the economic value of employee 
performance. New York, NY: AMACOM Div American Mgmt Assn.

Fornell, C., \& Larcker, D.F. (1981). Evaluating structural equation models with unobservable variables and measurement error. Journal of marketing Research, 18(1), 39-50.

Freel, M.S., \& Robson, P. J. (2004). Small firm innovation, growth and performance: Evidence from Scotland and Northern England. International Small Business Journal, 22(6), 561-575.

García-Merino, J.D., García-Zambrano, L., \& Rodriguez-Castellanos, A. (2014). Impact of Relational Capital on Business Value. Journal of Information \& Knowledge Management, 13(01), 1450002.

García-Muiña, F.E., \& PelechanoBarahona, E. (2008). The complexity of technological capital and legal protection mechanisms. Journal of Intellectual Capital, 9(1), 86-104.

Grant, R.M. (1991). The resource-based theory of competitive advantage: implications for strategy formulation. California management review, 33(3), 114135.

Hair, J.F., Black, W., Babin, B., \& Anderson, R. (2009). Multivariate Data Analysis (Vol. 7). New Jersey: Prentice Hall.

Hair, J.F. Ringle, C.M., \& Sarstedt, M. (2011). PLS-SEM: Indeed a silver bullet. Journal of Marketing theory and Practice, 19(2), 139-152.

Henard, D.H., \& Szymanski, D.M. (2001). Why some new products are more successful than others. Journal of marketing Research, 38(3), 362-375.

Hormiga, E., Batista-Canino, R.M., \& Sánchez-Medina, A. (2011). The Impact of Relational Capital on the Success of New Business Start-Ups. Journal of Small Business Management, 49(4), 617-638.
Kannan, G., \& Aulbur, W.G. (2004). Intellectual capital: measurement effectiveness. Journal of Intellectual Capital, 5(3), 389-413.

Khalique, M., Bontis, N., Abdul Nassir bin Shaari, J., \& Hassan Md. Isa, A. (2015). Intellectual capital in small and medium enterprises in Pakistan. Journal of Intellectual Capital, 16(1), 224-238.

Kim, D.-Y., \& Kumar, V. (2009). A framework for prioritization of intellectual capital indicators in R\&D. Journal of Intellectual Capital, 10(2), 277-293.

Kock, N. (2015). WarpPLS 5.0 User Manual. Laredo, TX: ScriptWarp Systems.

Kock, N., \& Lynn, G. (2012). Lateral collinearity and misleading results in variance-based SEM: An illustration and recommendations. Journal of the Association for Information Systems, 13(7), 546-580.

Leitner, K.-H. (2015). Intellectual Capital, Innovation, and Performance: Empirical Evidence From SMEs. International Journal of Innovation Management, 19(05), 1550060 .

Lev, B. (2000). Intangibles: Management, measurement, and reporting. Washington, DC: Brookings Institution Press.

Love, J.H., \& Roper, S. (2015). SME innovation, exporting and growth: A review of existing evidence. International Small Business Journal, 33(1), 28-48.

Luo, X., Griffith, D.A., Liu, S.S., \& Shi, Y.-Z. (2004). The effects of customer relationships and social capital on firm performance: A Chinese business illustration. Journal of International Marketing, 12(4), 25-45.

Marimuthu, M., Arokiasamy, L., \& Ismail, M. (2009). Human capital development and its impact on firm performance: Evidence from developmental economics. The journal of international social research, 2(8), 265- 
272.

Massa, S., \& Testa, S. (2008). Innovation and SMEs: Misaligned perspectives and goals among entrepreneurs, academics, and policy makers. Technovation, 28(7), 393-407.

McNamara, K. (2008). The Global Textile and Garments Industry: the role of information and communication technologies (ICTs) in exploiting the value chain. InfoDev. www. infodev. org/en/Document, 582.

Mohsin, M., Bashir, M., \& Latif, A. (2013). The Effect of Information Technology (IT) Support on Innovations Concepts: A study of Textile Sector in Pakistan. International Journal of Academic Research in Business and Social Sciences, 3(3), 105113.

Preacher, K.J., \& Hayes, A.F. (2008). Asymptotic and resampling strategies for assessing and comparing indirect effects in multiple mediator models. Behavior research methods, 40(3), 879-891.

Raymond, L., Bergeron, F., \& Croteau, A.M. (2013). Innovation capability and performance of manufacturing SMEs: The paradoxical effect of IT integration. Journal of Organizational Computing and Electronic Commerce, 23(3), 249-272.

Roos, G., \& Roos, J. (1997). Measuring your company's intellectual performance. Long range planning, 30(3), 413-426.

Roos, J., Edvinsson, L., \& Dragonetti, N. C. (1997). Intellectual capital: Navigating the new business landscape. London: Macmillan Press.

Roper, S., Du, J., \& Love, J. H. (2008). Modelling the innovation value chain. Research policy, 37(6), 961-977.

Santos-Rodrigues, H., Dorrego, P.F., \& Jardon, C.F. (2010). The influence of human capital on the innovativeness of firms. The International Business \& Economics Research Journal, 9(9), 53-64
Santos-Rodrigues, H., Fernández-Jardón, C.M., \& Dorrego, P. F. (2015). Relation between intellectual capital and the product process innovation. International Journal of Knowledge-Based Development, 6(1), 15-33.

Schreyer, P. (2001). The OECD productivity manual: a guide to the measurement of industry-level and aggregate productivity. International Productivity Monitor, 2(Spring), 37-51.

Sharabati, A.-A. A., Naji Jawad, S., \& Bontis, N. (2010). Intellectual capital and business performance in the pharmaceutical sector of Jordan. Management decision, 48(1), 105-131.

Singapore, S. (2011). A guide to integrated management of productivity activities (impact). Solaris Singapore SPRING Singapore.

Sivalogathasan, V., \& Wu, X. (2015). Impact of organization motivation on intellectual capital and innovation capability of the textile and apparel industry in Sri Lanka. International Journal of Innovation Science, 7(2), 153-168.

Sousa, C.M. (2004). Export performance measurement: an evaluation of the empirical research in the literature. Academy of marketing science review, 9, 1-22.

Stewart, T. (1997). The new wealth of organizations. Nicholas Brealey, London.

Subramaniam, M., \& Youndt, M.A. (2005). The influence of intellectual capital on the types of innovative capabilities. Academy of management journal, 48(3), 450463.

Trott, P. (2008). Innovation management and new product development. Harlow, England: Pearson education.

Verbano, C., \& Crema, M. (2016). Linking technology innovation strategy, intellectual capital and technology innovation performance in manufacturing SMEs. 
Technology Analysis \& Strategic

Management, 28(5), 524-540.

Vila, N., \& Kuster, I. (2007). The importance of innovation in international textile firms. European journal of marketing, 41(1/2), 17-36.

Wang, W.Y., \& Chang, C. (2005). Intellectual capital and performance in causal models: Evidence from the information technology industry in Taiwan. Journal of Intellectual Capital, 6(2), 222-236.

Wang, Z., Wang, N., \& Liang, H. (2014). Knowledge sharing, intellectual capital and firm performance. Management decision, 52(2), 230-258.

Wang, Q., Zhao, X., \& Voss, C. (2016). Customer orientation and innovation: A comparative study of manufacturing and service firms. International Journal of Production Economics, 171, 221-230.

Wernerfelt, B. (1984). A resource-based view of the firm. Strategic management journal, 5(2), 171-180.

White, S.D., Griffith, D.A., Ryans, J.K., \& Jr. (1998). Measuring export performance in service industries. International Marketing Review, 15(3), 188-204.

Zangoueinezhad, A., \& Moshabaki, A. (2009). The role of structural capital on competitive intelligence. Industrial Management \& Data Systems, 109(2), 262280. 